\title{
Antiproliferative Potential of Extracts from Kappaphycus Seaweeds on HeLa Cancer Cell Lines
}

(Potensi Antiproliferatif Ekstrak Rumpai Laut Kappaphycus ke atas Titisan Sel Kanser HeLa)

\author{
TieK Ying Lau, Delbora Fenny VitTal, CASSANDRA SZE YiI CHEW \\ \& WILSON THAU LYM YONG*
}

\begin{abstract}
A review of the current literature indicates that natural seaweeds are an excellent source of bioactive compounds with antioxidant, antimicrobial and antitumor properties. In the present study, 90\% methanolic, 70\% acetonic and aqueous extracts from Kappaphycus alvarezii (strains Crocodile, Giant and Brown) and Kappaphycus striatum were used to inhibit the growth of HeLa cell lines. MTS assay was carried out to determine the proliferation of HeLa cells in the presence of different seaweed extracts. Both $500 \mu \mathrm{g} / \mathrm{mL}$ of aqueous and methanolic extracts from $\mathrm{K}$. striatum demonstrated highest anti-proliferative activity against HeLa cells with cell growth inhibition of 53.5 and 43.7\%, respectively. Treatment with the aqueous extracts from three strains of $\mathrm{K}$. alvarezii did not show any growth inhibition against HeLa cell lines. The acetonic extract of Kappaphycus seaweeds exhibited a very poor cell growth inhibition with inhibitory activity observed under the treatment of 300 to $500 \mu \mathrm{g} / \mathrm{mL}$ of K. alvarezii strain Brown only. Further studies are suggested to identify and purify the specific anti-tumoral compounds for potential use in cancer therapy.
\end{abstract}

Keywords: Antiproliferation; growth inhibition; Kappaphycus alvarezii; Kappaphycus striatum

\section{ABSTRAK}

Suatu kajian kepustakaan semasa menunjukkan bahawa rumpai laut semula jadi adalah sumber komponen bioaktif yang sangat baik dengan aktiviti antioksidan, antimikrobial dan antitumor. Dalam kajian ini, ekstrak metanol 90\%, aseton $70 \%$ dan akueus daripada Kappaphycus alvarezii (strain Buaya, Giant dan Brown) dan Kappaphycus striatum telah digunakan untuk merencat pertumbuhan titisan sel HeLa. Asai MTS telah dijalankan untuk mengkaji pertumbuhan sel HeLa dalam kehadiran pelbagai ekstrak rumpai laut. Kedua-dua $500 \mu \mathrm{g} / \mathrm{mL}$ ekstrak akueus dan metanol daripada K. striatum menunjukkan aktiviti antiproliferasi yang tertinggi terhadap sel HeLa masing-masing dengan perencatan pertumbuhan sel sebanyak 53.5 dan 43.7\%. Rawatan dengan ekstrak akueus daripada tiga strain K. alvarezii tidak menunjukkan perencatan pertumbuhan terhadap titisan sel HeLa. Ekstrak aseton daripada rumpai laut Kappaphycus mempamerkan perencatan pertumbuhan sel yang lemah dengan aktiviti perencatan hanya boleh diperhatikan dengan rawatan 300 hingga $500 \mu \mathrm{g} / \mathrm{mL}$ daripada K. alvarezii strain Brown sahaja. Kajian lanjutan adalah dicadangkan untuk mengenal pasti dan menulenkan komponen khusus antitumor untuk pembangunan terapi kanser.

Kata kunci: Antiproliferasi; Kappaphycus alvarezii; Kappaphycus striatum; perencatan tumbuhan

\section{INTRODUCTION}

Seaweeds are considered to be a source of bioactive compounds as they are able to produce a variety of secondary metabolites characterized by a broad spectrum of biological activities. Compounds with cytostatic, antiviral, anthelmintic, antifungal and antibacterial activities have been detected in green, brown and red algae (Lindequist \& Schweder 2001; Newman et al. 2003). More recently, seaweeds are reported to be a rich source of antioxidant compounds (Duan et al. 2006; Kuda et al. 2005; Lim et al. 2002). For example, chlorophylls, carotenoids, tocopherol derivatives such as vitamin $\mathrm{E}$ and related isoprenoids, which are structurally related to plant-derived antioxidants, were found in some marine organisms including seaweeds (Takamatsu et al. 2003). Antioxidants in biological systems have multiple functions, including defense against oxidative damage and participating in the major signaling pathways of cells. Besides, some compounds from the seaweeds have antibacterial activities with potential use as mosquito control agents. Extracts from Eucheuma denticulatum have exhibited antibacterial activity on Gram positive organisms including Staphylococcus aureus and Streptococus pyogenes (Al-Haj et al. 2009).

Seaweeds also contain bioactive substances with great potential as antitumoral drugs, which lead to emerging interests in the biomedical research in seaweeds (Michio et al. 1984; de Sousa et al. 2007). Several species of seaweeds are rich sources of polysaccharides and glycoproteins with immune-stimulant, anticancer or antiviral activity (AbdelFattah et al. 1974; de Sousa et al. 2007; Michio et al. 1984; Nishino et al. 1989; Smit 2004). Certain algae have long been used in traditional Chinese herbal medicine in cancer 
treatment (Yamamoto et al. 1984). Red and green algae have been shown to demonstrate protective effects against mammary, intestinal and skin carcinogenesis (Yuan \& Walsh 2006). Zandi et al. (2010) reported that cold water extract of red alga, Gracilaria corticata, possessed biological activity against tumor cells replication. In recent years, much attention has been focused on fucoidan, a sulphated polysaccharide derived from brown seaweeds. Recent studies evidenced that fucoidan has strong antitumor activity and exhibited important roles against human cancer cell lines (Ly et al. 2005; Matsuda et al. 2010). Fucoidan was found to be able to suppress the growth of tumor cells in vivo and activate the immune system against tumors (Itoh et al. 1993; Maruyama et al. 2003; Noda et al. 1990; Usui et al. 1980; Yamamoto et al. 1984; Zhuang et al. 1995).

The two red seaweed species, $K$. alvarezii and $K$. striatum, which are extensively distributed in Sabah, have been uncovered as a novel source for a variety of compounds such as dietary fibers, vitamin $\mathrm{C}, \alpha$-tocopherol, minerals, fatty acid and protein (Matanjun et al. 2008). However, there is limited information about their biological activity on cancer cell growth inhibition. The objectives of this study were to screen and evaluate the anti-proliferative activities of crude methanolic, acetonic and aqueous extracts of selected strains of $K$. alvarezii and $K$. striatum. The information compiled during the course of this study can be of use for further development of cancer therapy.

\section{MATERIALS AND METHODS}

\section{SAMPLES PREPARATION}

Kappaphycus alvarezii (strains Crocodile, Giant and Brown) and Kappaphycus striatum were collected from Semporna, Sabah. The samples were washed with fresh water and dried at room temperature for 1 week. The dried seaweed samples were separately milled and subjected to compound extractions. For aqueous extraction, dry powder of seaweed was macerated with de-ionized water and filtered through cotton wool and Whatman (No. 1) filter paper to remove debris. The filtrate was lyophilized using freeze dryer for 3 days. For each of extraction using $90 \%$ methanol and $70 \%$ acetone, approximately $100 \mathrm{~g}$ of powdered seaweed samples were extracted using a soxhlet apparatus. The methanol and acetone were purchased from Sigma-Aldrich (St. Louis, MO, USA). About $500 \mathrm{~mL}$ of each solvent was used to carry out the extraction in soxhlet apparatus for a period of 24-72 $\mathrm{h}$ until the solvent becomes colorless at $65 \pm 2^{\circ} \mathrm{C}$. The solvent was evaporated using a rotary vacuum evaporator to make the final volume onefourth of the original volume. The methanolic, acetonic and aqueous extracts were stored in $-10^{\circ} \mathrm{C}$ for further analysis of anti-proliferative assay in triplicate.

\section{CELL LINE AND CULTURE CONDITION}

HeLa Cancer Cell Line CCL-23 $3^{\mathrm{TM}}$ was purchased from American Type Culture Collection (ATCC®, USA). Cells were seeded and grown in RPMI (Roswell Park Memorial Institute) media. They were maintained in $12.5 \mathrm{~cm}^{3} \mathrm{BD}$ Falcon ${ }^{\mathrm{TM}}$ cell culture flask (California, USA) at $37^{\circ} \mathrm{C}$ in a humidified atmosphere with $5 \% \mathrm{CO}_{2}$. The RPMI medium was replaced once every two days and passaging was performed to maintain the adherent cell lines.

\section{GROWTH INHIBITION ASSAY}

In order to observe the seaweed extracts responsiveness, a cell proliferation assay was carried out. The inhibition effects of methonolic, acetonic and aqueous extracts on the growth of HeLa cells were evaluated in vitro by the MTS assay. This method relies on the ability of dehydrogenase enzymes in the metabolically active cells to convert 3-(4,5-dimethylthiazol-2-yl)5-(3-carboxymethoxy phenyl)-2-(4-sulfophenyl)-2Htetrazolium or MTS to a formazan precipitate. The Cell Titer 96 ${ }^{\circledR}$ Aqueous Non-Radioactive Cell Proliferation Assay purchased from Promega (Madison, USA) was used to determine the cell proliferation of HeLa cells in the presence of different types of extracts (methanolic, acetonic and aqueous) at different concentrations (50, $100,200,300,400$ and $500 \mu \mathrm{g} / \mathrm{mL})$. The different concentrations of each extracts were prepared from the stock solutions by serial dilution.

A known number of HeLa cells $\left(10^{4}\right)$ were incubated in 96-well plates in a volume of $200 \mu \mathrm{L}$ of culture medium and permitted to adhere for $24 \mathrm{~h}$ before addition of test compounds. About $100 \mu \mathrm{L}$ of different concentrations $(50,100,200,300,400$ and $500 \mu \mathrm{g} / \mathrm{mL})$ of each extracts (methanolic, acetonic and aqueous) were added to the cells. After $48 \mathrm{~h}$ of exposure, the cells were washed with $100 \mu \mathrm{L}$ of phosphate-buffered saline (PBS) and replaced with fresh medium. Approximately $20 \mu \mathrm{L}$ of CellTiter $96^{\circledR} \mathrm{AQ}_{\text {uеous }}$ One Solution Reagent was added into each well of the 96-well assay containing the samples in $100 \mu \mathrm{L}$ of culture medium. The plates were incubated at $37^{\circ} \mathrm{C}$ in a humidified atmosphere with $5 \% \mathrm{CO}_{2}$. Following incubation for $4 \mathrm{~h}$, the plates were read with SPECTRAMax M2 ROM (Molecular Devices) microplate reader at absorbance of $490 \mathrm{~nm}$. The experiments were performed twice in triplicate. The results were evaluated by comparing the absorbance of the treated cells with the absorbance of wells containing cell treated by the solvent control. Conventionally, cell viability was estimated to be $100 \%$ in the solvent control.

\section{DATA ANALYSES}

Percentage of cell growth inhibition versus extracts concentration was calculated according to Patel et al. (2009) as follow:

Percentage of cell growth inhibition $=100-[(\mathrm{A}-\mathrm{B}) /$ (C-B)] $\times 100$,

where $\mathrm{A}$ is the absorbance of sample; $\mathrm{B}$ is the absorbance of blank and $\mathrm{C}$ is the absorbance of control. 


\section{RESULTS}

MTS assay was carried out to investigate the inhibition effects of methonolic, acetonic and aqueous extracts of Kappaphycus seaweeds on the growth of HeLa cells and the results are represented in Figures 1 to 4 . Six different concentrations $(50,100,200,300,400$ and $500 \mu \mathrm{g} /$ $\mathrm{mL}$ ) of each extract (methanolic, acetonic and aqueous) were applied. Figure 1 shows the percentage of growth inhibition against $90 \%$ methanolic, $70 \%$ acetonic and aqueous extracts of $K$. alvarezii strain Crocodile. Among the three types of extracts, only methanolic extract from 200 to $500 \mu \mathrm{g} / \mathrm{mL}$ showed obvious anti-proliferative activity against the HeLa cells. The highest percentage $(31.7 \%)$ of growth inhibition was observed with the treatment using $300 \mu \mathrm{g} / \mathrm{mL}$ of methanolic extract. This was followed by the treatment using methanolic extracts at 400 , 500 and $200 \mu \mathrm{g} / \mathrm{mL}$ with $24.6,16.5$ and $4.0 \%$ of growth inhibition, respectively. Treatments with 50 and $100 \mu \mathrm{g} / \mathrm{mL}$ methanolic extracts and all acetonic and aqueous extracts did not show any growth inhibition but they promoted growth of the treated cells instead.

For the treatment with different extracts from $K$. alvarezii strain Giant, only methanolic extract at $400 \mu \mathrm{g} /$ $\mathrm{mL}$ demonstrated growth inhibition $(8.5 \%)$ as summarized in Figure 2. Methanolic extract with other concentrations and all the acetonic and aqueous extracts from $K$. alvarezii strain Giant did not show any cell growth inhibition. While for the treatment with $K$. alvarezii strain Brown extracts, the highest growth inhibition $(30.4 \%)$ was observed with $50 \mu \mathrm{g} / \mathrm{mL}$ of methanolic extract, as shown in Figure 3. Increment of methanolic extract concentrations resulted in decrement of growth inhibition as seen with 100 and $200 \mu \mathrm{g} / \mathrm{mL}$ of extracts demonstrated 7.9 and $5.9 \%$ of growth inhibition, respectively. On the other hand, only acetonic extract from this strain demonstrated positive antiproliferative activity against the HeLa cells as compared with the other two strains (Crocodile and Giant). Increment of acetonic extract from 300 to $500 \mu \mathrm{g} / \mathrm{mL}$ had parallel increment in the inhibition percentage from 17.5 to $29.7 \%$.

Figure 4 shows the percentage of cell growth inhibition against concentrations of methanolic, acetonic and aqueous extracts of $K$. striatum. The results indicated that all the methanolic and aqueous extracts have positive inhibition on the HeLa cell lines. Treatment with the aqueous extract ranging from 50 to $500 \mu \mathrm{g} / \mathrm{mL}$ exhibited concentration dependent anti-proliferative activity against HeLa cells with 17.8 to $53.5 \%$ of cell growth inhibition. Whereas, the inhibition effect of methanolic extract on cells growth ranged from 6.2 to $43.7 \%$. All acetonic extracts from $K$. striatum did not inhibit, but promote, cell growth.

\section{DISCUSSION}

Marine algae contain many unidentified useful components and physiologically active substances. Studies on bioactivity of marine algae against cancer cell lines have been reported in previous researches, where the findings have brought great promise to the development of cancer treatment activities (Albano et al. 1990; Berlinck et al. 1996). Some studies involved general extractions of seaweeds while others applied extraction of specific metabolites such as carotene, bromophenols and carrageenan (Ly et al. 2005; Xu et al. 2004). In the present study, $90 \%$ methanolic extracts, $70 \%$ acetonic extracts and aqueous extracts of $K$. alvarezii and $K$. striatum were studied for their potential to inhibit the growth of HeLa cell lines. The most effective concentration to inhibit cell growth was found to be $500 \mu \mathrm{g} / \mathrm{mL}$ of aqueous extract of $K$. striatum followed by $500 \mu \mathrm{g} / \mathrm{mL}$ of methanolic extract of same species, with 53.5 and $43.7 \%$ of growth inhibition, respectively. These differences in antitumor activities may be attributed to their different molecular weights, charge characteristics and monosaccharide distributions (Dias et al. 2005).

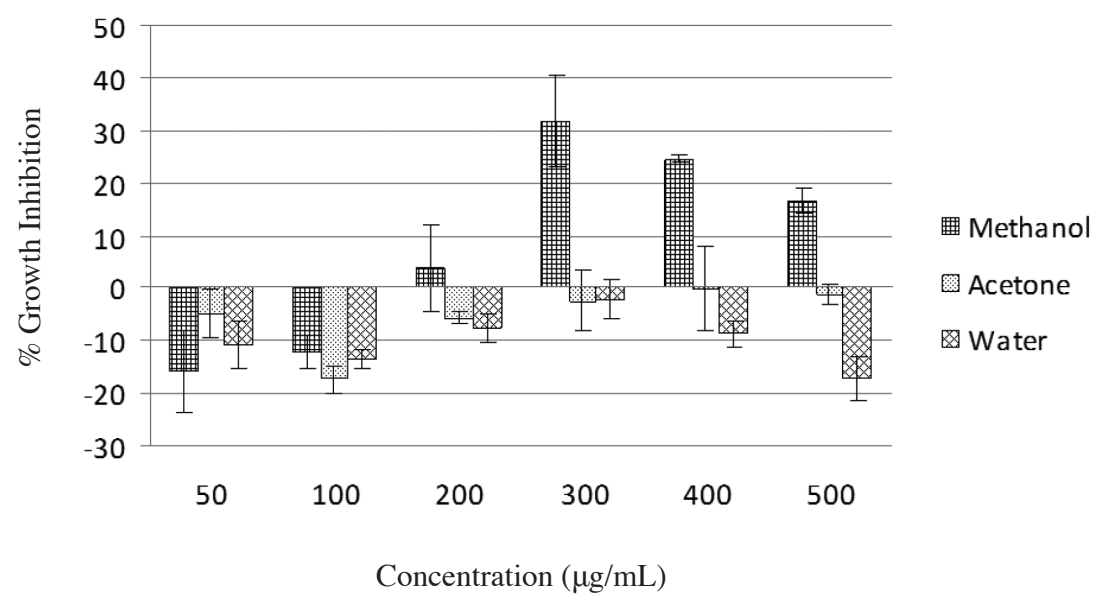

FIGURE 1. Percentage of growth inhibition of HeLa cell lines in the presence of $90 \%$ methanolic, $70 \%$ acenotic and aqueous extracts of $K$. alvarezii strain Crocodile.

Data points show the mean \pm SE for a minimum of three experiments 


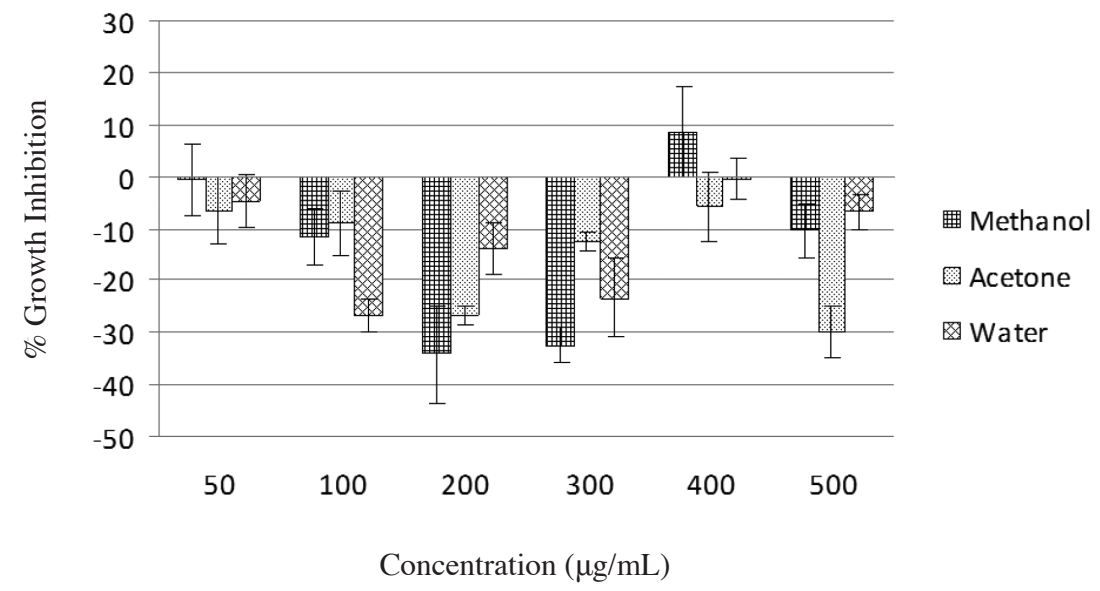

FIGURE 2. Percentage of growth inhibition of HeLa cell lines in the presence of $90 \%$ methanolic, $70 \%$ acenotic and aqueous extracts of $K$. alvarezii strain Giant.

Data points show the mean \pm SE for a minimum of three experiments

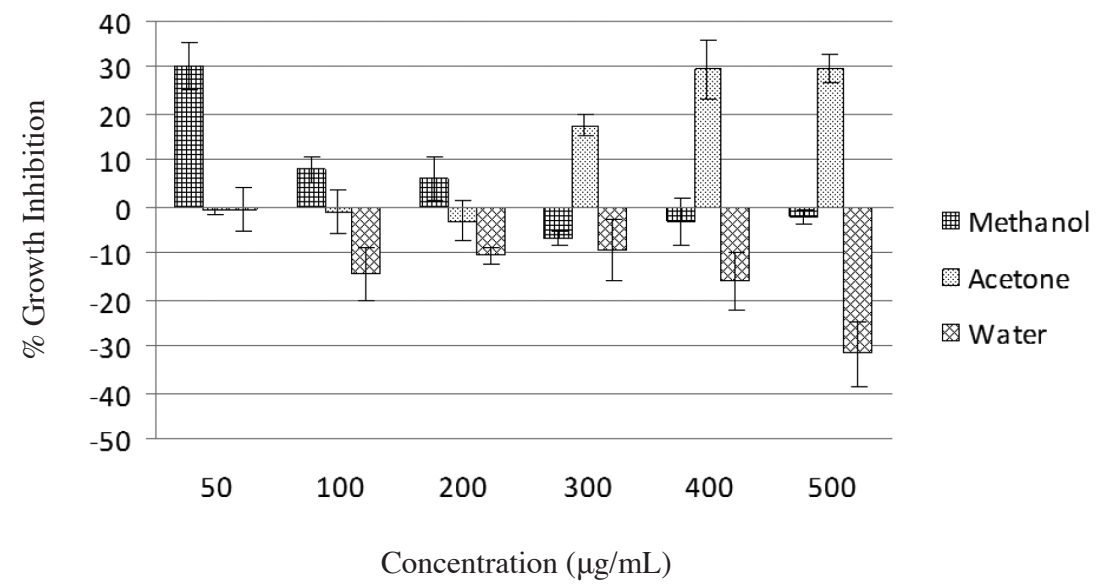

FIGURE 3. Percentage of growth inhibition of HeLa cell lines in the presence of 90\% methanolic, $70 \%$ acenotic, and aqueous extracts of K. alvarezii strain Brown. Data points show the mean $\pm \mathrm{SE}$ for a minimum of three experiments

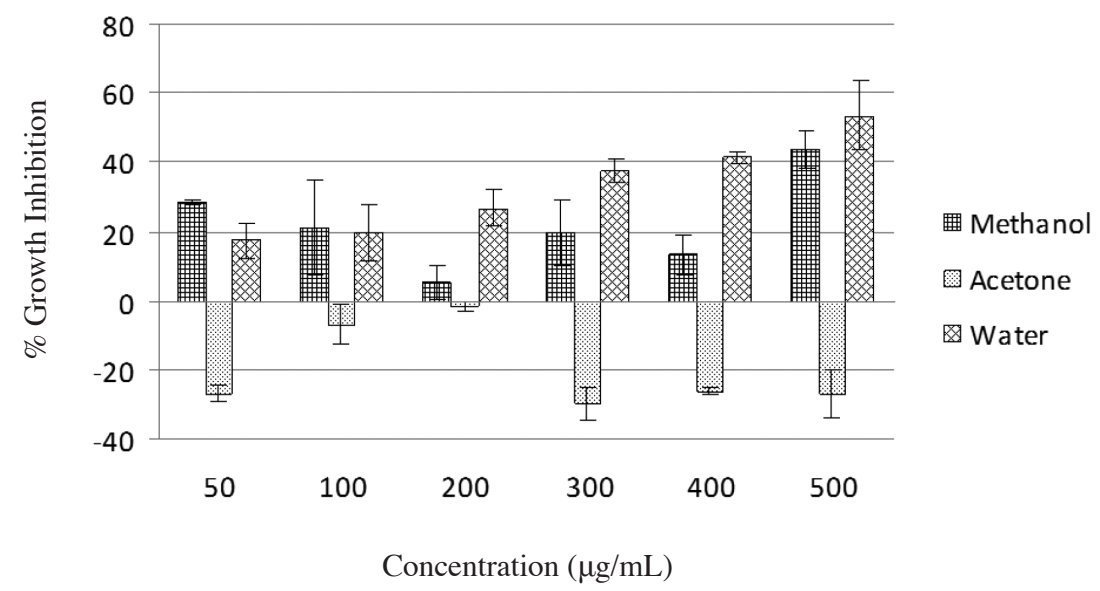

FIGURE 4. Percentage of growth inhibition of HeLa cell lines in the presence of $90 \%$ methanolic, $70 \%$ acenotic and aqueous extracts of $K$. striatum. Data points show the mean \pm SE for a minimum of three experiments 
Previous studies reported that alcoholic extracts from plant samples exhibited several bioactivities such as adaptogenic, anti-flammatory, anticonvulsant, sedative, androgenic and immunopromoting activities ( $\mathrm{Xu}$ et al. 1992). This might be the reason why methanolic extracts from Kappaphycus seaweeds generally showed positive growth inhibition to the HeLa cell lines as compared with acetonic and aqueous extracts. Studies by Shao et al. (1996) also reported that alcoholic extract from asparagus shoots exhibited antitumor activities and Singh et al. (1992) reported their fruit to be the source of bile-stimulating agent. Reports from World Intellectual Property Organization (2010) also indicated that methanolic extracts from various seaweed species have demonstrated cytotoxic effect on human cancer cell lines including HeLa, MCF-7 and MDAMB-231. Alcohol is found to be effective to extract active compounds such as biophenols, lipids, saccharides, minerals and small peptides due to their polarity. The potential bioactive compounds in seaweed may interact with special cancer associated receptors or cancer specific molecules to trigger the mechanisms leading to cancer cell death.

Previous researches show that acetone-water mixtures are good solvent systems for the extraction of polar antioxidants (Lu \& Yeap Foo 1999; Luximon-Ramma et al. 2005; Sun 2002). Literature also describes that acetone and water extracts of plant flowers presented the best total phenolic content (Liu et al . 2009). Nyenje and Ndip (2011) suggested that an organic solvent, in particular, acetone is a good solvent as it extracts more active compounds from plant material. Flavonoids and steroids have also been reported to be extracted using acetone according to Abdulmalik et al. (2011) and Eloff (1998). Besides, van Slambrouck et al. (2007) demonstrated that crude aqueous extracts of L. tridentata (Creosote Bush) and J. communis $L$. (Juniper Berry) have significantly decreased the growth of MCF-7/AZ breast cancer cells. Traditional medicines are often prepared by water extraction, but water-soluble impurities present challenges for conventional isolation methods, such as chromatography or crystallization (Bart 2011). Water preferentially extracts polar compounds but they need some special post treatment such as ion exchange or caustic wash for further purification (Jones \& Kingkorn 2006).

Further studies are suggested to identify the specific anti-tumoral compounds in the targeted extracts. Purification can be carried out to obtain the bioactive compounds for the development of cancer therapy. Besides, identification of specific metabolites such as carotene, bromophenols and carrageenan from seaweeds is also recommended for the discovery of potential antiproliferative or anticancer compounds.

\section{ACKNOWLEDGEMENTS}

The authors wish to thank the Ministry of Education (MOE), Malaysia for funding the research under the Fundamental Research Grant Scheme (FRG0201-SG-1/2010).

\section{REFERENCES}

Abdel-Fattah, A.F., Hussein, M.M. \& Salem, H.M. 1974. Studies of the purification and some properties of sargasan, a sulphated heterpolysaccharide from Sargassum linifolium. Carbohydrate Research 33: 9-17.

Abdulmalik, I.A., Sule, M.I., Musa, A.M., Yaro, A.H., Abdullahi, M.I., Abdulkadir, M.F. \& Yusuf, H. 2011. Isolation of steroids from acetone extract of Ficus iteophylla. British Journal of Pharmacology and Toxicology 2: 270-272.

Albano, R.M., Pavao, M.S.G., Mourao, P.A.S.\& Mulloy, B. 1990. Structural studies of a sulfated L-galactan from Styela plicata (Tunicate): Analysis of the Smith-degraded polysaccharide. Carbohydrate Research 208: 163-174.

Al-Haj, N.A., Mashan, N.I., Shamsudin, M.N., Mohamad, H., Vairappan, C.S. \& Sekawi, Z. 2009. Antibacterial activity in marine algae Eucheuma denticulatum against Staphylococcus aureus and Streptococcus pyogenes. Research Journal of Biological Sciences 4: 519-524.

Bart, H.J. 2011. Extraction of natural products from plants - An introduction. In Industrial Scale Natural Products Extraction. 1st ed., edited by Bart, H.J. \& Pilz, S. Weinheim: Wiley-VCH Verlag GmbH \& Co. KGaA. pp. 1-25.

Berlinck, R.G.S., Ogawa, C.A., Almeida, A.M.P., Sanchez, M.A.A., Malpezzi, E.L.A., Costa,L.V., Hajdu, E. \& de Freitas, J.C. 1996. Chemical and pharmacological characterization of halitoxin from Amphimedon viridis (Porifera) from the southeastern Brazilian coast. Comparative Biochemistry and Physiology Part C: Pharmacology, Toxicology and Endocrinology 115: 155-163.

de Sousa, A.P.A., Torres, M.R., Pessoa, C., de Moraes, M.O., Filho, F.D.R., Alves, A.P.N.N. \& Costa-Lotufo, L.V. 2007. In vivo growth-inhibition of Sarcoma 180 tumor by alginates from brown seaweed Sargassum vulgare. Carbohydrate Polymers 69: 7-13.

Dias, P.F., Siqueira, J.M., Vendruscolo, L.F., de Jesus Neiva, T., Gagliardi,A.R., Maraschin, M. \& Ribeiro-do-Valle, R.M. 2005. Antiangiogenic and antitumoral properties of a polysaccharide isolated from the seaweed Sargassum stenophyllum. Cancer Chemotherapy and Pharmacology 56: 436-446.

Duan, X.J., Zhang, W.W., Li, X.M.\& Wang, B.G. 2006.Evaluation of antioxidant property of extract and fractions obtained from a red alga, Polysiphonia urceolata. Food Chemistry 95: 37-43.

Eloff, J.N. 1998. Which extractant should be used for the screening and isolation of antimicrobial components from plants? Journal of Ethnopharmacology 60: 1-8.

Itoh, H., Noda, H., Amano, H., Zhuang, C., Mizuno, T. \& Ito, H. 1993. Antitumor activity and immunological properties of marine algal polysaccharides, especially fucoidan, prepared from Sargassum thunbergii of phaeophyceae. Anticancer Research 13: 2045-2052.

Jones, W.P. \& Kingkorn,A.D. 2006. Extraction of plant secondary metabolites - Natural Products Isolation. In Methods in Biotechnology. vol. 20, 2nd ed., edited by Sarker, S.D., Latif, Z. \& Gray, A.I. Totowa, New Jersey: Humana Press. pp. 323-351.

Kuda, T., Tsunekawa, M., Goto, H. \& Araki, Y. 2005. Antioxidant properties of four edible algae harvested in the Noto Peninsula, Japan. Journal of Food Composition and Analysis 18: 625-633.

Lim, S.N., Cheung, P.C.K., Ooi, V.E.C. \& Ang, P.O. 2002. Evaluation of antioxidative activity of extracts from a brown seaweed, Sargassum siliquastrum. Journal of Agricultural and Food Chemistry 50: 3862-3866.

Lindequist, U. \& Schweder, T. 2001. Marine biotechnology. In 
Biotechnology, vol. 10, edited by Rehm, H.J. \& Reed, G. Weinheim: Wiley-VCH. pp. 441-484.

Liu, S.C., Lin, J.T., Wang, C.K., Chen, H.Y. \& Yang, D.J. 2009. Antioxidant properties of various solvent extracts from lychee (Litchi chinenesis Sonn.) flowers. Food Chemistry 114: 577581.

Lu, Y. \& Yeap Foo, L. 1999. The polyphenol constituents of grape pomace. Food Chemistry 65: 1-8.

Luximon-Ramma,A., Bahorun, T., Crozier, A.,Zbarsky, V., Datla, K.P., Dexter, D.T. \& Aruoma, O.I. 2005. Characterization of the antioxidant functions of flavonoids and proanthocyanidins in Mauritian black teas. Food Research International 38: 357-367.

Ly, B.M., Buu, N.Q., Nhut, N.D., Thinh, P.D., Thi, T. \& Van, T. 2005. Studies on fucoidan and its production from Vietnamese brown seaweeds. Asean Journal for Science and Technology Development (AJSTD) 22: 371-380.

Matanjun, P., Mohamed, S., Mustapha, N.M., Muhammad, K. \& Ming, C.H. 2008. Antioxidant activities and phenolics content of eight species of seaweeds from north Borneo. Journal of Applied Phycology 20: 367-373.

Maruyama, H., Tamauchi, H., Hashimoto, M. \& Nakano, T. 2003. Antitumor activity and immune response of Mekabu fucoidan extracted from Sporophyll of Undaria pinnatifida. In vivo 17: 245-249.

Matsuda, Y., Teruya, K., Matsuda, S., Nakano, A., Nishimoto, T., Ueno, M., Niho, A., Yamashita, M., Eto, H., Katakura, Y. \& Shirahata, S. 2010. Anti-cancer effects of enzymedigested fucoidan extract from seaweed Mozuku. Animal Cell Technology: Basic \& Applied Aspects 16: 295-300.

Michio, F., Noriko, I., Ichiro, Y. \& Terukazu, N. 1984. Purification and chemical and physical characterization of an antitumor polysaccharide from the brown seaweed Sargassum fulvellum. Carbohydrate Research 125: 97-106.

Newman, D.J., Cragg, G.M. \& Snader, K.M. 2003. Natural products as source of new drugs over the period 1981-2002. Journal of Natural Products 66: 1022-1037.

Nishino, T., Yokoyama, G., Dobashi, K., Fujihara, M. \& Nagumo, T. 1989. Isolation, purification and characterization of fucosecontaining sulphated polysaccharides from the brown seaweed Ecklonia kurome and their blood-anticoagulant activities. Carbohydrate Research 186: 119-129.

Noda, H., Amano, H., Arashima, K. \& Nisizawa, K. 1990. Antitumor activity of marine algae. Hydrobiologia 204-205: 577-584.

Nyenje, M. \& Ndip, R.N. 2011. In-vitro antimicrobial activity of crude acetone extract of the stem bark of Combretum molle against selected bacterial pathogens. Journal of Medicinal Plants Research 5: 5315-5320.

Patel, S., Gheewala, N., Suthar, A. \& Shah, A. 2009. In-vitro cytotoxicity activity of Solanum nigrum extract against Hela cell line and Vero cell line. International Journal of Pharmacy and Pharmaceutical Sciences 1: 38-46.

Shao, Y., Chin, C.K., Ho, C.T., Ma, W., Garrospm, S.A. \& Huang, M.T. 1996.Anti-tumor activity of the crude saponins obtained from asparagus. Cancer Letters 104: 31-36.

Singh, A.K., Hussain, A., Srivastava, G.N., Misra, L.N., Gupta, M.M., Virmani, O.P., Popli, S.P. \& Abraham, Z. 1992. Dictionary of Indian Medicinal Plants. Lucknow, India: Central Institute of Medicinal and Aromatic Plants (CIMAP).

Smit, A.J. 2004. Medicinal and pharmaceutical uses of seaweed natural products: A review. Journal of Applied Phycology 16: 245-262.
Sun, S.G. 2002. Reply to the comments on the paper by Zheng M.S. and Sun S.G. entitled 'In situ FTIR spectroscopic studies of $\mathrm{CO}$ adsorption on electrodes with nanometerscale thin films of ruthenium in sulphuric acid solutions' by Pecharromán, C., Cuesta, A. \& Gutiérrez, C. Journal of Electroanalytical Chemistry 529: 155-158.

Takamatsu, S., Hodges, T.W., Rajbhandari, I., Gerwick, W.H., Hamann, M.T. \& Nagle, G. 2003. Marine natural products as novel antioxidant prototypes. Journal of Natural Products 66: 605-608.

Usui, T., Asari, K. \& Mizuno, T. 1980. Isolation of highly purified "Fucoidan" from Eisenia bicylclis and its anticoagulant and antitumor activities. Agricultural and Biological Chemistry 44: 1965-1966.

van Slambrouck, S., Daniels, A.L., Hooten, C.J., Brock, S.L., Jenkins, A.R., Ogasawara, M.A., Baker, J.M., Adkins, G., Elias, E.M., Agustin, V.J., Constantine, S.R., Pullin, M.J., Shors, S.T., Kornienko, A. \& Steelant, W.F.A. 2007. Effect of crude aqueous medicinal plant extracts on growth and invasion of breast cancer cells. Oncology Reports 17: 14871492.

Xu, J.P., Xu, R.S. \& Li, X.Y. 1992. Four new cycloartane saponins from Curculigo orchioides. Planta Medica 58: 208-210.

Xu, N., Fan, X., Yan, X. \& Tseng, C.K. 2004. Screening marine algae from China for their antitumor activities. Journal of Applied Phycology 16: 451-456.

Yamamoto, I., Takahashi, M., Suzuki, T., Seino, H. \& Mori, H. 1984. Antitumor effect of seaweeds. IV. Enhancement of antitumor activity by sulfation of a crude fucoidan fraction from Sargassum kjellmanianum. The Japanese Journal of Experimental Medicine 54: 143-151.

Yuan, Y.V. \& Walsh, N.A. 2006. Antioxidant and antiproliferative activities of extracts from a variety of edible seaweeds. Food and Chemical Toxicology 44: 1144-1150.

Zandi, K., Tajbakhsh, S., Nabipour, I., Rastian, Z., Yousefi, F., Sharafiah, S. \& Sartavi, K. 2010. In vitro antitumor activity of Gracilaria corticata (a red alga) against Jurkat and molt-4 human cancer cell lines. African Journal of Biotechnology 9: 6787-6790.

Zhuang, C., Itoh, H., Mizuno, T. \& Ito, H. 1995. Antitumor active fucoidan from the brown seaweed, umitoranoo (Sargassum thunbergii). Bioscience, Biotechnology, and Biochemistry 59: 563-567.

Tiek Ying Lau, Cassandra Sze Yii Chew

\& Wilson Thau Lym Yong*

Biotechnology Research Institute

Universiti Malaysia Sabah, Jalan UMS

88400 Kota Kinabalu, Sabah

Malaysia

Delbora Fenny Vittal

School of Science and Technology

Universiti Malaysia Sabah, Jalan UMS

88400 Kota Kinabalu, Sabah

Malaysia

*Corresponding author; email: wilsonyg@ums.edu.my

Received: 10 March 2013

Accepted: 24 April 2014 